\title{
Socio-economic impact of the International Waterway E60 on the Polish and Lithuanian coastal regions
}

\author{
Marcin Kalinowski ${ }^{1}$,Rafat $\mathrm{Koba}^{1}$, and Magdalena Matczak $^{2}$ \\ ${ }^{1}$ Maritime Institute in Gdańsk, Economics and Law Department, Długi Targ 41/42, 80-830 Gdańsk, Poland \\ ${ }^{2}$ Maritime Institute in Gdańsk, Spatial Planning Laboratory, Długi Targ 41/42, 80-830 Gdańsk, Poland
}

\begin{abstract}
International Waterway E60 (IWW E60) is a sea-shore route running from Gibraltar to the North along European coast up to St. Petersburg then through the Baltic-White Sea Channel, then along the White Sea coast to Arkhangelsk. From the German-Polish border, along the Polish, Russian and Lithuanian coast to the Lithuanian-Latvian border, the route is $610 \mathrm{~km}$-long and runs along 32 Polish municipalities and 4 Lithuanian regions. Determining the role of IWW E60 is important in the context of economic growth of municipalities and coastal regions, especially through the development of local seaports. Operations of the multifunctional port have a wide economic and social impact. Mutual interaction of functions can be observed on the example of fisheries, where in the port area fishing functions intermingle with the processing, tourism, storage and distribution function. The main socioeconomic benefits of E60 waterway development include the increase in employment, economic activity, generation of added value and improvement of transport infrastructure. In addition, ports influence attractiveness of the regions and create impulse for new jobs in the tourism industry. Until now there have been no attempts to make E60 route navigable or only on short sections, usually between two neighbouring ports. Despite the significant cross-border importance of this connection, no directions for its optimal development were defined. What is more, the route is not used. In connection with this, steps were taken to thoroughly investigate the problem and determine the possibility of its development as part of inland waterways network.
\end{abstract}

\section{Introduction}

The International Waterway E60 (IWW E60) is a sea-shore route running from Gibraltar to the North along the coasts of Portugal, Spain, France, Belgium, the Netherlands, Germany, Poland, Lithuania, Latvia, Estonia, Russia to the Sankt-Peterburg-Volga-Baltic waterway, then through the Baltic - Białomorski Channel, then along the White Sea coast to Arkhangelsk.

The E60 route on the Polish and Lithuanian sections runs along 32 Polish municipalities and 4 Lithuanian districts. In Poland, these are the following municipalities: Świnoujście, Międzyzdroje, Wolin, Dziwnów, Rewal, Trzebiatów, Kołobrzeg (urban and rural), Ustronie Morskie, Będzino, Mielno, Darłowo (urban and rural), Postomino, Ustka (urban and rural), Smołdzino, Łeba, Choczewo, Krokowa, Władysławowo, Jastarnia, Hel, Puck (urban and rural), Kosakowo, Gdynia, Sopot, Gdańsk, Stegna, Sztutowo and Krynica Morska. In Lithuania, these are the regions of: Klaipeda, Nering, Palanga and Silute. Polish municipalities have 1,070,032 inhabitants and occupy an area of 376914 ha. In Lithuanian regions live 269,044 people and have an area equal to 332200 ha. In total, the areas affected by the E60 waterway in 2015 were inhabited by 1339076 people and had an area of 709 114 ha. The following table provides detailed information on the study area.

Table 1. Data of communes and municipalities of the Polish and Lithuanian coast (2015)

\begin{tabular}{|c|c|c|c|c|}
\hline \multicolumn{5}{|c|}{ Poland (year 2015) } \\
\hline Region & County & Commune & Population & Area, ha \\
\hline \multirow{8}{*}{ Zachodniopomorskie } & Świnoujście & Świnoujście & 41152 & 1971323 \\
\hline & \multirow{3}{*}{ Kamieński } & Międzyzdroje & 6543 & 11438 \\
\hline & & Wolin & 12281 & 32746 \\
\hline & & Dziwnów & 4004 & 3762 \\
\hline & \multirow{2}{*}{ Gryficki } & Rewal & 3891 & 4065 \\
\hline & & Trzebiatów & 16565 & 1025 \\
\hline & \multirow[t]{2}{*}{ Kołobrzeski } & $\begin{array}{l}\text { Kołobrzeg (miejska i } \\
\text { wiejska) }\end{array}$ & 57284 & 16970 \\
\hline & & Ustronie Morskie & 3663 & 5698 \\
\hline
\end{tabular}




\begin{tabular}{|c|c|c|c|c|}
\hline & \multirow{2}{*}{ Koszaliński } & Będzino & 8576 & 16619 \\
\hline & & Mielno & 5006 & 6213 \\
\hline & \multirow{2}{*}{ Sławieński } & $\begin{array}{l}\text { Darłowo (miejska i } \\
\text { wiejska) }\end{array}$ & 22016 & 28966 \\
\hline & & Postomino & 7036 & 22686 \\
\hline \multirow{16}{*}{ Pomorskie } & \multirow{2}{*}{ Słupski } & Ustka (miejska i wiejska) & 24275 & 22765 \\
\hline & & Smołdzino & 3431 & 26029 \\
\hline & Lęborski & Łeba & 3789 & 1481 \\
\hline & Wejherowski & Choczewo & 5630 & 18313 \\
\hline & \multirow{6}{*}{ Pucki } & Krokowa & 10673 & 21109 \\
\hline & & Władysławowo & 15467 & 3922 \\
\hline & & Jastarnia & 3824 & 780 \\
\hline & & Hel & 3531 & 2172 \\
\hline & & Puck (miejska i wiejska) & 36772 & 24217 \\
\hline & & Kosakowo & 12813 & 5014 \\
\hline & Gdynia & Gdynia & 247478 & 13514 \\
\hline & Sopot & Sopot & 37231 & 1728 \\
\hline & Gdańsk & Gdańsk & 462249 & 26196 \\
\hline & \multirow{3}{*}{ Nowodworski } & Stegna & 9844 & 17009 \\
\hline & & Sztutowo & 3685 & 11153 \\
\hline & & Krynica Morska & 1323 & 11601 \\
\hline & \multicolumn{2}{|r|}{ Total: } & 1070032 & 376914 \\
\hline & \multicolumn{4}{|c|}{ Lithuania (year 2015) } \\
\hline & County & Municipality & Population & Area, ha \\
\hline & \multirow{4}{*}{ Klaipeda } & Klaipeda & 208972 & 143900 \\
\hline & & Neringa & 2879 & 9000 \\
\hline & & Palanga & 15379 & 7900 \\
\hline & & Silute & 41814 & 171400 \\
\hline & \multicolumn{2}{|r|}{ Total: } & 269044 & 332200 \\
\hline & \multicolumn{2}{|r|}{$\begin{array}{r}\text { lotal: } \\
\text { TOTAL: }\end{array}$} & 1339076 & 709114 \\
\hline
\end{tabular}

Source: Own elaboration based on GUS - Local Data Bank and Lithuanian Statistical Office

From the German - Polish border, along the Polish, Russian and Lithuanian coasts to the Lithuanian - Latvian border, this route is about $610 \mathrm{~km}$ long. Within the catchment area of this waterway, there are local seaports of the Polish and Lithuanian coast, such as: Kołobrzeg, Darłowo, Ustka, Władysławowo, Jastarnia, Hel, Svientoi Butinge and two ports located on the Curonian Spit which connect with the E60 route through the International Waterway E70. The course of the E60 waterway is shown in Figure 1.

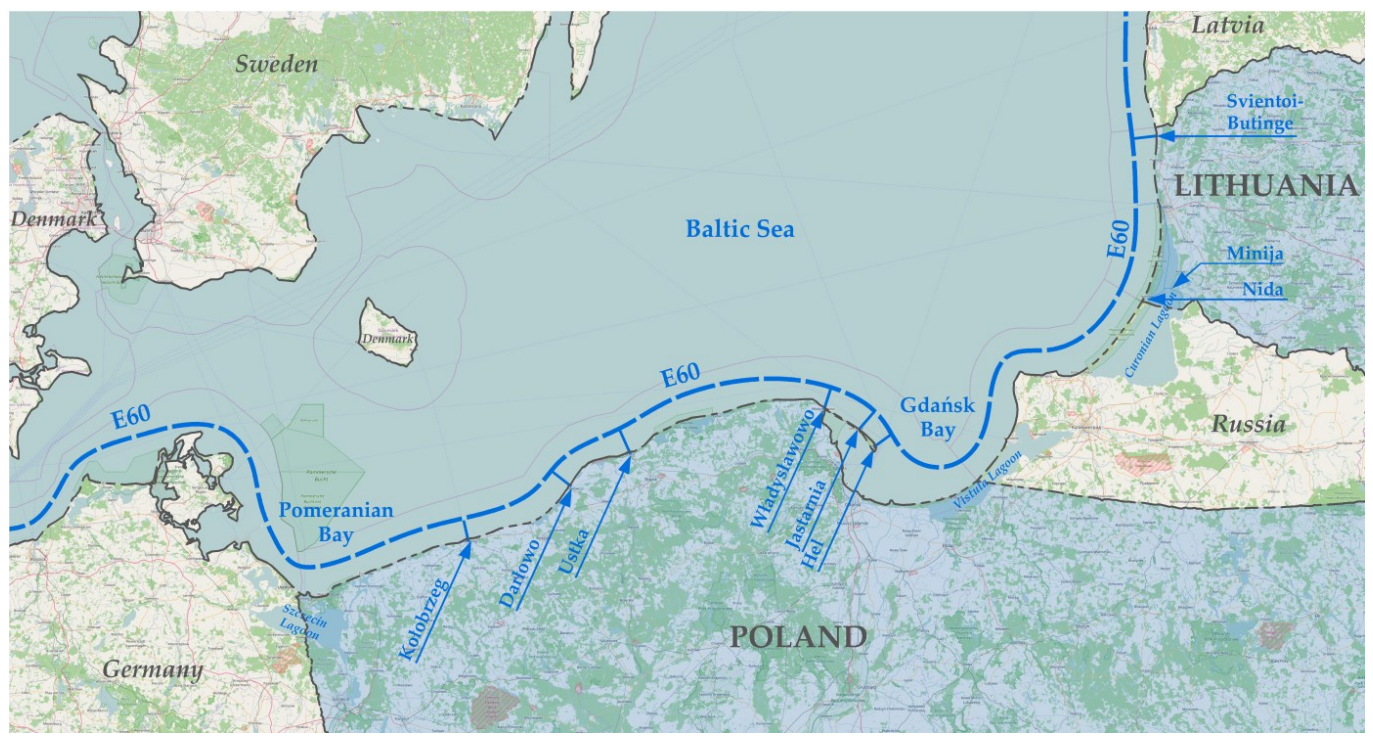

Fig.1. Seashore route E60 on the Poland - Lithuania section

Source: Own elaboration based on OpenStreetMap and Inventory of Main Standards and Parameters of the E Waterway Network, Economic Commission for Europe Inland Transport Committee United Nations, New York and Geneva 2012. 
The E60 route has enormous tourist potential and can become a very important link between the local ports of Poland and Lithuania. All ports are located in areas of high tourist value, therefore the launch of passenger tourism on this route could attract many tourists.

Currently, regular ferry tourism along the IWW E60 does not exist. Regular lines in Poland connect only Kołobrzeg and Bornholm. Tourism between the local ports of Poland and Lithuania does not function due to legal and administrative constraints, difficult border crossing procedures, military zones closed to traffic and marine areas of landscape parks. The E60 route has big tourist potential, but there are many barriers that prevent its use. While it is possible to overcome barriers on the Polish and Lithuanian side, one should remember about the section of the Russian Federation existing along the Kaliningrad Oblast. In the territorial waters of this section there are both Russian military areas, which completely exclude any traffic of tourist vessels, as well as the area of the Curonian Spit landscape park, which is also a significant impediment. Therefore, the E60 route in its present form will be able to function only if close cooperation is established with the Kaliningrad Region and local ports on its coast.

Strengthening the role of IWW E60 is important in the context of economic growth of municipalities and coastal regions, in particular through the development of local seaports. Multifunction port operations have a wide economic and social impact. Mutual interaction of functions can be observed on the example of fisheries, where in the port area the fishing functions are mixed with processing, tourism, storage and distribution functions. The main socio-economic benefits associated with the development of the E60 waterway include increased employment, economic activity, the generation of added value and the improvement of transport infrastructure. In addition, ports affect the attractiveness of regions and create an impulse for new jobs in the tourism industry. Until now, no attempts have been made to navigate the E60 route or have been undertaken only on short distances, usually between two neighbouring ports. Despite the significant cross-border importance of this connection, no directions for its optimal development have been identified. Therefore, an attempt was made to examine the problem and determine the possibilities of its development, mainly in the context of the operation of local seaports. This article presents the synthesis of research results on the problem identified above.

\section{Local ports as development centres}

In the maritime policy of the state, seaports of fundamental importance for the development of the country's economy play an important role and they are privileged, especially when it comes to financing port investments. Countries such as Poland and Lithuania in their policies should also focus not only on these major ports but also link the development of maritime economy with the whole coast and take full advantage of the coastal location. Local ports are key in this respect. The standard and scope of services offered by these ports determines whether the use of the entire seashore will be limited to boarding houses and the beach, or whether it will be more comprehensive. This is particularly important due to the occurrence of such phenomena as:

- Environmental protection conditions make it necessary to limit the Baltic fishery, whose service should be one of the basic functions of local ports,

- A typical beach season at the Baltic Sea is very short,

- The growing wealth of the society creates pressure on a more varied offer for those who vacation by the sea,

- The open borders of the South Baltic countries create conditions for the development of short-sea passenger transport.

The proper development of local ports, which are still on the margins of the national maritime policy, will determine whether these factors will have a positive impact on the development of the coast.

The current European Union policy on integrated coastal zone management requires a comprehensive approach and recognition of all aspects of opportunities offered by coastal location for local communities on the entire coastline.

The issue of the possibility of developing local ports is also included in the broader spatial context, including not only their near-land (local and regional) terrestrial, but also maritime foreland, as the projected intensification of sea space use for various economic purposes should also result in new development impulses for local ports.

Research carried out as part of the SB LocPorts project allowed to identify barriers to the development of local ports, among which the most serious ones were:

- Economic barrier manifested in the lack of funds for financing port investments and other developmental plans,

- Legal and organizational barriers expressed in numerous restrictions imposed on local ports, which significantly hinder the development of port operations, 
- Lack of efficient mechanisms of cooperation between stakeholders or those that should be interested in the development of local ports.

Based on the analysis, the possibilities of activating local ports were developed. One of the results of the analyses is the statement that the basic assumption of the local market economic recovery plan is to link the development of economic activity with the intensive and extensive use of existing or modernized port infrastructure. The type of activity that will include the broadest possible range of services based on and port infrastructure is of key importance. Local ports, due to their impact on the local and regional economy, should be treated as centers of economic development, i.e. centers that can indirectly significantly affect the national economy and therefore their importance cannot be undermined, especially in strategic national documents and laws regulating the seaports activities.

Taking advantage of the opportunities offered by the port requires the implementation of many investments, both in the field of port infrastructure facilities providing access to ports and ICT infrastructure that creates an efficiently functioning integrated information system, unified for all ports of the South Baltic Sea Region. In order for these investments to give the desired synergy effects, national authorities should create a clear vision of the development of the coastal regions and set directions for economic and functional-spatial development, which will allow integration of international, national and local social and economic interests. Obvious in this respect will be the beneficial impact of the waterway E60, which will undoubtedly create a strong impulse for economic development.

Formulating detailed proposals of actions that would allow to overcome, or at least reduce developmental barriers, requires in-depth research. It seems particularly important to undertake research on the place of local ports in regional policy and on the creation of regular maritime connections along the coast of the South Baltic countries, using the international waterway E60, which will undoubtedly have a positive effect on the activation of ports and regions in which they are located. It should also be borne in mind that the reduction of capital and thus infrastructure barriers will not be possible without full use of the possibilities offered by public-private partnership.

\section{Local ports economic impact on the surrounding region}

Poland and Lithuania, being member states of the European Union, the problem of cross-border cooperation between local ports could be solved at the EU level. However, current EU policy is targeted at the 300 largest European seaports and they have priority in granting funding for development. Local ports have a very difficult task.

The local ports of the Polish and Lithuanian coasts are located in poorly industrialized regions with high natural and tourist values. Therefore, cross-border cooperation between them should be implemented mainly on the basis of maritime tourism. However, to make this possible, many barriers have to be overcome. One of them is complicated and restrictive border procedures. The sea border crossing should provide adequate control, which must be efficient, fast, well-functioning and friendly to tourists.

In order for Maritime tourism to function, proper infrastructure and an integrated information system are needed. Uniform for all ports, providing tourists with information in a legible and easily accessible way. EU funds have a positive impact on the state of infrastructure in local ports, which is improving every year, but there is still much to do.

When the local ports of the Polish and Lithuanian coasts are fully adapted to passenger traffic, the next step should be to navigate the international waterway E60, running along the coast and connecting all the ports discussed.

The location of local ports is closely related to the development of economic functions of the immediate environment. The functioning of the port, in addition to certain financial effects, also has a fairly wide economic impact on the immediate surroundings. The main, though hard to measure, economic benefits include, among others, the possibility of reducing unemployment, economic activation of the region or an increase in tax revenues.

On the scale of the entire Polish coast, there is a great diversity between the communes where the ports and marinas are located. In the coastal areas there are numerous economic entities with different profiles and sizes. The spatial diversity of the number of economic entities is also relatively high, but their number decreases as the distance from larger agglomerations increases.

In economic activities in coastal communes, the largest share is market services, which include, among others, transport and warehouse management, as well as activities related to accommodation and gastronomy. An important area of activity is also industrial processing or fishing related activities. In the port cities, the largest number of companies deals with hotel services and conducts gastronomic activities. Other important activities are trade and repairs, business and real estate services, industry, construction and transport. The predominance of the tourist function is clearly visible. 
As part of the sustainable development strategy, small sea ports have the role of economic activation centers for coastal regions. The state's regional and transport policy must be coordinated in order to avoid divergence of priorities, which would lead to the dispersion of financial resources from both structural and national funds.

Of particular importance among the factors determining the socio-economic development of cities and communes is the existing and anticipated transport infrastructure. Public transport is connected with the city's transport system, which should contribute to the development of areas through which transport routes run. The communication system and its efficiency to a large extent determine the possibilities of economic growth and create favourable conditions for the development of entrepreneurship. Entrepreneurship is one of the most important factors of socio-economic development and increase in competitiveness of coastal regions (other regions as well). Therefore, effective support for entrepreneurship should be an integral element of municipal and regional authorities. A positive example of this activity is the Kołobrzeg city support program for entrepreneurship, which assumes direct support through specific activities supporting local companies and indirect - through the implementation of a number of infrastructure investments that improve the functioning of the city.

The location relative to the back office and the foreground is an important factor in the implementation of the local port's transport function and economic activation. The meaning of the local port in the transport chain can be most generally expressed by the amount of cargo handled. In the case of large universal ports, the search for directions of service diversification led to the emergence of a distribution function, which is a synthesis of transport and commercial functions and resulted in the creation of logistics centers. At the basis of the development of the distribution function there is a need to improve the distribution of goods and services moved between production and consumption. In this context, in the era of increasing congestion in road transport and the tendency to implement modern logistic solutions and the concept of transferring cargo from roads to the sea, local ports have a potential chance of development as ports supporting large port centers. Therefore, local ports should activate the traditional transport function. Of course, it is necessary to create an appropriate infrastructure system.

\section{Influence on local job market}

Due to the complexity of their functions, seaports create large labour markets around them. The analyzed areas of local ports and their immediate surroundings create many employment opportunities. These ports generate employment in fisheries, processing and preservation of fish and fishery products. Besides, they are attractive to tourists in themselves. Thanks to this, they increase the attractiveness of the region and are an impulse to create new jobs in the tourism industry.

The coastal location and associated landscape features favour the development of tourism. The most popular form of tourism in the studied area is tourism, which results directly from the coastal location. For climate reasons, this type of tourism is limited almost exclusively to the summer season, and in addition largely depends on the current weather conditions. Active tourism, especially water tourism is also very popular. Regions offer conditions for sailing, windsurfing and kitesurfing enthusiasts. Tourism generates a lot of jobs, both in accommodation and gastronomy facilities, as well as recreation and entertainment facilities. In addition, tourists spending holidays in the vicinity of local ports benefit from services related to everyday life (hairdresser, beautician, car mechanic, doctor, etc.). This is a circumstance that may be an additional opportunity for industries not related to tourism.

Sea ports have always been a great job market, especially the so-called simple work. However, along with technological changes within particular port functions, and especially in the transport function, the importance of ports as a source of quantitative demand for labour decreases, analogously to that in industry. However, the importance of skilled work increases. From the point of view of the port-region relationship, it is difficult not to notice the relationship between the possibilities of port development and the possibilities of acquiring qualified staff.

In this connection, the port-region relationship has been observed in recent years. It is not the port that is the development stimulus of the city, but the development of the port depends on the impulses flowing from its surroundings. This applies to both education and accessibility of the port from the back office, which was a traditional "contact" of the city and port, as well as a new problem - joint port-urban activities for the optimal use of urban and port space.

Regardless of the size and significance of a given port, it is always an important component of development potential in the scale of the commune, region and country, and as part of the local development potential, each local port should be subject to local government policy shaped at the commune level.

The activity of the majority of local ports in Poland is mainly associated with fishing and, to a limited extent, with support for tourism and recreation. Few of the local ports form modest, though multifunctional, economic and spatial structures of both local and regional importance, capable of the typical operation of transport hubs.

The fishing industry is diverse, however, the fluctuations in its production in recent years appear in all types of activities related to it. Each area is also struggling with other problems, such as high maintenance costs, good environmental status, poorly developed port infrastructure or catch limits. This affects the condition of the fisheries sector, which more often tells related entrepreneurs to think about diversifying their activities. 
In the Puck Bay area, employment in fisheries is characterized by a smaller share of young people (up to 30 years of age) than the average in Poland (8.8\% to 13.5$)$ and larger older people (over 60$)(13.1 \%$ to 8$), 9 \%)$. In turn, in the years 2007-2013, the number of people working in the processing and preservation of fish and fishery products both in the Puck Land region and in the region remained at a similar level.

Among the employed in processing, women dominate all the time (59.6\%). Current MIR estimates indicate that this area comprises $45.2 \%$ of employees on fishing vessels (at sea and on land) in the Pomeranian Region and $1 / 4$ of domestic employment. In 2014, the highest number of employees was in Władysławowo (217, i.e. $41.0 \%$ of the total) and in Jastarnia (208 people, i.e. 39.3\%).

The coastal location of the Puck Land area and the unique environment and landscape values associated with it favour the development of tourism. The area of the Puck Land, as well as the entire Pomorskie Region, is considered one of the most attractive tourist regions in Poland. It is characterized by natural and cultural values, whose diversity and uniqueness on the national scale affect the high attractiveness of tourists visiting the region, but also for residents who positively assess their place of residence. The most popular form of tourism in the studied area is tourism, which results directly from the coastal location and landscape values of the region. Active tourism, especially water tourism is also very popular. The region offers excellent conditions for sailing enthusiasts, but there is no common and integrated offer of the entire region for sailors. In this region there are excellent conditions for windsurfing. The surroundings of Rewa and Jastarnia are very popular among kitesurfing fans. This information is also confirmed by the already mentioned LQ indicator. In 2014, it amounted to more than 5.5 for accommodation and food service activities. The scale of development of the sector is provided by data on the increase in accommodation facilities (between 2010 and 2014 by $327.6 \%$, with the region average of $80.1 \%$ and the country's $37.2 \%$ ), and consequently beds (respectively $53.1 \%, 21,1 \%$ and $13.8 \%$ ), which means the regular development of the tourism sector and the steadily growing number of employed in tourism.

In the area of the Słowińska Grupa Rybacka, which includes the Ustka Port, there are 20 fish processing plants operate. Most of them have modern equipment and modernized or new infrastructure. MORPOL S.A., the largest fish processing plant in Europe and salmon in the world, has the largest share in production and employment. The health tourism is of major importance for the economic development of the SGR area, mainly Ustka Uzdrowisko, covering the City of Ustka and the Ustka commune part and, therefore, also a seaport. Ustka as one of 45 places in the country (in the Pomeranian Region - Sopot and Ustka) has the status of a health resort, which is an opportunity to extend the tourist season. The number of facilities providing accommodation services is above average, which reflects the tourist character of the region. In 2014, almost 137 thousand tourists rested in the SGR area that had at their disposal 11,500 beds in 131 facilities. The most developed accommodation base is located in the rural commune of Ustka, in which $52.7 \%$ of beds are concentrated, and their number, similarly to people using it, increases. $43 \%$ of accommodation is located in the City of Ustka, which is most often chosen by tourists for summer holidays (54.9\% of the total number of guests.) The above data, similar to the surroundings of the local ports of the Bay of Puck, indicate a high level of employment in the tourism industry and its growing trend. Mostly it is connected with the seaport in Ustka and its immediate surroundings as well as the tourist attractions it creates.

In Darłowo Local Fisheries Group, within which the Port of Darłowo operates, there are 23 fisheries farms (some of them have many breeding and hatching centers scattered throughout the area) and 15 factories. In the fisheries sector (excluding processing) about 350 people are employed.

The type of business activity that is particularly important in the opinion of DLGR are tourist and tourismrelated services. The nature potential is evidenced by the fact that legally protected areas occupy $17.1 \%$ of the area and there are more than 300 nature monuments on them. Tourism is one of the key potentials of the DLGR area due to the proximity of the Baltic Sea, attractive landscape, numerous lakes and tourist attractions. Data on the tourism services sector, however, indicate that the potential of the area is not fully used. According to the data at the end of 2013, there were 119 accommodation facilities in the DLGR area, half of them located in the city of Darłowo.

In the area of the Local Fishing Group "Morze i Parsęta", in which the Port of Kołobrzeg functions, in fulltime fishing activity in 2013, 321 people were employed, including 250 at sea. With regard to data for the region in the area of SRLGD, over $29 \%$ of those working in fishing were employed, while in the case of nationwide data over $12.5 \%$. According to the data contained in the RRW-19 forms, in 2014 in the municipalities belonging to SRLGD "Sea and Parsęta", there were 237 employees. The submitted forms concerned 44 units, or $64.4 \%$ of the size of the fleet registered in the municipalities of Kołobrzeg, Kołobrzeg and Ustronie Morskie commune at the end of 2014. Almost $80 \%$ of people working in the area of SRLGD "Morze i Parsęta" were employed in fishing units. This was a lower result than in most ports in Poland (average 87.3\%).

Every year, over 400,000 people visit the region of SRLGD "Sea and Parsęta", mainly due to the sea port in Kołobrzeg. This number, thanks to the stays in the spa, spreads out throughout the year, with the highest volume of tourist traffic falling into the holiday season. This has an impact on the seasonality of employment in the area. This number is an additional, potential clientele of local enterprises. Of course, the expenses of tourists in the largest part are intended for accommodation, gastronomy, entertainment and recreation. However, it should be remembered that tourists staying in the area covered by LDS usually spend here at least a week. 
In Lithuania the influence of the Šventoji seaport development on local job market depends very much upon the pace of reconstruction and marketing success. Altogether, it is expected that new 10 to 50 jobs can be created in Šventoji in maritime and ancillary services in relation to the seaport development. In assessing the prospects for the seaport development, two scenarios can be distinguished: a) if the port restoration is relatively slow, this growth could be restrained to $5-10 \%$; b) in the case if the economic indicators of the port will start to improve after the reconstruction in 2020, and over the next five years will improve steadily each year, this growth may reach 20 to $30 \%$.

The greatest demand for skilled and non-skilled labour force associated with the growth of the Šventoji seaport is related to the demand for catering to the visiting leisure boats and small-scale ferries in the summer season. According to statistics obtained from the existing Lithuanian and Latvian marinas, one can predict that the Šventoji seaport marina will be visited by 500-600 yachts and motor boats annually with foreigners comprising over $70 \%$ of the visitors. During the first year of operation of the reconstructed seaport (first season) over 200 foreign boats can be expected arriving from Germany, Poland, Latvia, Russia, and the Nordic countries(Finland, Sweden, Denmark), if the information about the new marina will be successfully spread in the targeted foreign markets.

Pending upon successful development of Palanga resort marketing activities in the Nordic countries, we can expect at least 1-2 small ferry lines from these countries during the first 2-3 years of operation of the seaport, which would be particularly receptive to the skilled and unskilled labour force onshore. A significant increase in the labour force employed in the Šventoji seaport and the marina servicing the maritime and ancillary sectors can be facilitated by special events (e.g., an international Tall ship race), daily management of the Šventoji harbour, as well as by additional ground services in the leisure and informal education services (eg., a sailing club, a sailing school etc.). As will be mentioned below, there is a permanent demand for skilled labour force related to the maintenance of the fleet of service vessels of various institutions, i.e. the Lithuanian Navy, the Būtinge oil terminal, the Environment Protection Agency, and the State Border Guard Service. The impact of the Būtinge oil terminal on the local labour market is negligible since the staff is sufficient and it mainly lives in Palanga or Klaipeda.

As it was already mentioned above, currently there are 10 fishermen keeping their vessels in the Nida harbour. Due to the decline of commercial fisheries in the Curonian Lagoon, it is hardly feasible that the number of the fishermen can increase in Nida in the foreseeable future, although the number of berths specifically allocated to the small-scale fishing boats could be increased up to 40 . On the other hand, increasing of the capacity of the dock for leisure boats can have some influence on the local labour market considering new port-related employment opportunities in direct and ancillary services. In spite of numerous restrictions and regulations related to the national park and World Heritage status, Neringa municipality is the leading one in Lithuania in terms of conditions for doing business. Hence, any upgrading of facilities for water tourism and leisure boating, particularly, opening of cross-border navigation to the Russian part of the Curonian Lagoon, might have a substantial positive impact on the local job market, especially in the summer season.

Due to the importance of water tourism and related services for the economy of the Minija village, in combination with rural tourism, angling and nature tourism services, and with addition of husbandry and smallscale ancillary fisheries, there is no structural unemployment in the Minija village. On the contrary, it attracts seasonal employees from as far as Kintai, the eldership centre, and Šilute, the municipality centre. The seasonality of tourism in Minija is mitigated by the circumstance, that most of the facilities, including the marina, are closed in the low season and the remaining few open ones are able to survive catering to the needs of a few hundreds of ice-fishing and birdwatching enthusiasts visiting the Minija river delta in winter and in spring.

Most of the inhabitants in the low season either live on the earnings accumulated during the tourist season, or leave the village. This is a quite typical situation for seasonal touristic settlements worldwide. It is definitely not a sustainable state of affairs as it is prone to fast collapse if conditions of tourism change. However, for Minija, which is a remote village with very limited development alternatives it might be seen as a quasi-equilibrium state concerning the local job market. Bearing in mind that Minija is an ethnographic and architectural heritage village where any new investment and development plans must meet very strict conservation requirements, there is hardly any chance for the settlement to expand beyond its current limits and for the revival of any larger scale commercial fisheries in the Curonian Lagoon by local inhabitants, whose number and economic welfare is relatively stable, but their interests are not in fisheries anymore.

\section{Barriers, opportunities and threats}

The most important limitations of the possibility of developing local ports include, first of all, the economic barrier evidenced by the lack of funds for financing investments and other development plans.

The existing statutory solution, which provides entities managing local ports and sea harbours (or directly to municipalities) with the possibility of acquiring certain properties, at the same time imposing certain obligations on those entities requiring significant expenses, does not create any mechanism ensuring real regular income for these entities. The functioning solution does not guarantee a regular mechanism ensuring the acquisition of funds required for the construction, modernization and maintenance of infrastructure providing access to ports and 
harbors. The burden of constructing, maintaining and modernizing port infrastructure imposed on entities managing these ports and marinas in practice is impossible without state support.

Regardless of the management model, ports and marinas have very limited possibilities of obtaining inflows to cover high investment costs. The tasks and objectives included in local port development strategies require the owner to be included in the implementation. The ports themselves can meet current needs and strategic goals, however, they are not able to generate funds to cover even the most urgent needs.

The development of local ports is also not conducive to the system of tax burdens for entities managing ports and harbors, depending on their right of ownership or perpetual usufruct of real estate and buildings and structures located within the boundaries of ports and marinas. Admittedly, due to the existing actual ownership relations, in many specific cases these encumbrances do not constitute a development barrier for existing local ports and marinas within their present boundaries, however, the cases of limiting the development needs of these ports and marinas due to the burden of taking over further real estate they are more and more frequent.

Direct support by separated management boards of ports (eg Kołobrzeg or Darłowo) of economic entities that can undertake to implement part of the strategy is limited. Nevertheless, port management may create favourable conditions for economic development, attracting investors, acquiring aid funds from the European Union, as well as inspire entrepreneurship of port users.

The activities of local port and municipal authorities should focus on seeking funding for access. The activities of coastal communes that do not take into account the proper development of transport infrastructure will not bring the desired effects, and will additionally limit the possibilities of dynamic development not only of ports but also of other segments of the economy. With neglected transport infrastructure and difficult access to expressways and transport network of national and European scope, tendencies to economic marginalization of areas with neglected transport infrastructure are intensifying.

Investments in the development of ports are usually capital-intensive, in addition they are characterized by a long period of return. Neither maritime offices nor municipalities, in areas where local ports and sea harbours are located, have large resources. The situation does not seem to change quickly.

Port managing entities do not finance the infrastructure providing access to the port, through which the act means those that lead to the port or marina and the fairways located within the port or marina, including facilities, facilities and institutions connected with their functioning. These facilities are financed from the state budget within the limits provided for in the budget act. By virtue of other regulations, entities other than managing ports have the responsibility for the construction, extension, modernization and maintenance of infrastructure facilities providing access to the port from the land side, such as roads, railways, waterways. This is a state of affairs typical of European ports and can be treated as one of the forms of public aid for ports.

Location barriers arise both from the geographical location, concerning all ports, and the specificity of the Polish and Lithuanian coasts. The Baltic Sea has a peripheral position in relation to the main shipping routes, which limits the development of seaports, including to some extent local ports. In addition, the cold climate means that passenger and sailing are seasonal and can be practiced from late spring to early autumn.

In the case of Polish and Lithuanian harbours and marinas, the situation is exacerbated by the slightly diversified coastline, which does not encourage the development of cabotage, as is the case in Sweden, Finland or Denmark. In addition, in the case of many local ports and marinas located above the open sea, we are dealing with silting the entrance to the port. This limits the usable depth of the fairways and causes significant dredging costs. Even worse is accessibility from the land side.

The economic environment of local ports is not conducive to their development. They adjoin agricultural areas, and the small local industry does not generate any needs for maritime transport. This is accompanied by a decrease in catches, and hence a decrease in the number of cutters and fishing boats based in small ports and harbours.

Each port has its own specificity, which results in its chances and threats. The following analysis is an attempt to compile those features that may be common to all or most of the local ports, and so subject to a certain generalization.

\section{Opportunities:}

- A growing awareness that local ports are the main factor in increasing the attractiveness of coastal communes, favouring the expansion of their offer and the extension of the tourist season.

- An increase in the level of affluence of the society, which increases the demand for sea tourism and the practice of yachting.

- Gradual improvement of infrastructure on the coast.

- Gradual acquisition of experience by local government activists and the growing pool of qualified personnel.

- Progress in solving priority investment tasks of municipalities (sewerage, sewage treatment, schools, etc.), which, by their very nature, were assessed as more important than ports.

- The development of tourism and passenger traffic in sailing as a result of the increase in the standard of living in Poland and the improvement of the port infrastructure. 
- Establishment of conditions for the development of other port functions.

- The possibility of using EU regional policy funds for the development of port infrastructure and access to ports from the sea and land.

- Development of cluster initiatives.

- A clear view of the major directions of port development in spatial development plans and development strategies of individual port municipalities.

- Linking investments in road infrastructure and tourist base of port communes with the development of ports.

Threats

- Weakness of links between local markets and abroad by the sea and a little varied shape of the coast,

- A short planning horizon, determined by the electoral calendar, at all levels of government.

- Lack of coherence of the activities of entities, on which the development of local ports, ie the government and all levels of local self-government depends.

- Spatial conflicts resulting from divergent interests in the coastal zone.

- Ecological fundamentalism, often with a corruption foundation.

- Capital limits.

- Poorly developed economic facilities of ports (mainly agricultural areas, low level of industrial development).

- Lack of the idea of part of port self-governments to use ports as important elements of the sustainable development of port centers.

- Too slow pace of improvement of the parameters of access infrastructure to ports from the land side.

\section{Conclusions}

Local ports, despite unfavourable conditions, can be an important factor in the activation of communes and coastal regions. For the proper development of local airports and their surroundings, a number of tools and legal and organizational instruments necessary to develop effective solutions are necessary. The development of local ports should at the same time be an integral part of the region, county and commune strategy.

Changes occurring in the structure of the national economy, including in the sectors related to the sea, make it necessary to change the destination of many port infrastructure facilities in local ports and to adapt them to new functions. In many cases, it is also necessary to modernize the infrastructure providing access to the port from the foreground (fairways, breakwaters, etc.) and from the back office (road and rail network).

Local ports and marinas are by definition the components of local infrastructure that provide the opportunity to take advantage of the opportunities offered by the coastal location. Hence, their functions are adapted to the forms of using the sea adopted by a given community. Basically, it should be mentioned here:

- providing access to a given section of the shore from the sea for cargo and passengers,

- handling of coastal and sea fishing using nearby benches,

- service of sport boats and various types of activities in the field of maritime tourism and recreation,

- providing conditions for the implementation of manufacturing activities related to the abovementioned functions, such as:

- storage and processing of fish,

- construction and repairs of small marine units, mainly fishing and sports.

In spite of generally unfavourable factors determining development and barriers, local ports undergo transformation and gradually adapt to changed legal and economic conditions. This process is not fast and diverse, mainly due to differences in the potential and determination of local authorities. In each case, there is a certain range of development opportunities and forms of acceleration of activation.

The activation of local ports and marinas should be based on the following assumptions:

- business development should be related to intensive and extensive use of existing and / or expandable infrastructure comprising port / harbours and maximization of utility resulting from access to the sea and use of its resources.

- activities that meet the above-mentioned conditions include the traditional transport services sector (port services, freight transport), services related to tourism services, Baltic fishing and services based on knowledge and modern technologies.

- expenditures incurred on the revitalization of seaports and marinas are relatively high, as they are associated with the deepening of basins, port channels and fairways to ports, modernization of 
breakwaters and wharves, construction of piers, shore protection, sea view terraces, promenades, etc. On the other hand, the types of activity developed on the basis of existing / modernized infrastructure facilities are usually too small as to the size and production time of infrastructure use, so that entities (public, private) could obtain any economies of scale, and local effects have significant effects positive feedback between the conducted activity and the increase in value added. The key from an economic point of view is therefore the development of activities, which will include the broadest possible range of services / production based on the available port / harbour infrastructure. In this way, economies of scale (not achievable in most local seaports) will be replaced by the benefits of the scope. The provision of a wide range of activities or the development of several types of production will increase the use of capital-intensive infrastructure, which will reduce the costs of its production engagement, and customers (tourists, recipients of products / services) will receive a bundle of goods and services in a given town.

- the activation of small ports and harbours according to the economies of the scope has a chance to be successful, provided that:

- business development will be based on the idea of locally created clusters, i.e. complementary chains and complementary services and types of production performed by cooperating private and public entities (local government and state),

- local clusters will develop functional relationships with such centers in other cities to the widest extent possible, and thus obtain additional benefits arising as a result of running and developing activities in the network of economic connections (network economies).

In creating clusters, it is necessary to initiate local authorities and create a platform that facilitates the partners' agreement and sometimes the creation of a public-private enterprise.

The activation of local ports and marinas finds their justification in theory and practice to stimulate the socioeconomic development of small and large economic systems. All European Union programs, whether related to sectoral policy (transport policy), industry policy (maritime policy) or horizontal policies (cohesion, sustainable development, competition, growth and employment), as well as regional development strategies developed by the European Union ( Strategy for the development of the Baltic Sea Region) are built largely on the assumptions presented above, which will undoubtedly facilitate public entities implementing the strategies of local development constructed in this way to access Community funds. It is also significant that the current attempts to develop local maritime communities based on other premises did not bring expected results in most cases.

Practical ways of activating local seaports / marinas / sea centers with the use of infrastructure, boil down to:

- development of maritime sports and tourist clusters and passenger navigation,

- development of fishing, recreational angling and mariculture,

- development of commodity production and traditional transport and reloading services,

- development of services related to knowledge and modern technologies.

Referring to the first of the above-mentioned items and in view of the fact that the Polish and Lithuanian local seaports discussed in this article are located in areas of high natural and tourist value, the development of sea tourism can be an important impulse for the development of ports and their surroundings. Attempts should be made to navigate the IWW E60 that runs along the coast. This trail has enormous tourist potential and can become a very important link between local and national ports both for Poland and Lithuania. The launch of passenger tourism on this route would undoubtedly be very interesting and would attract many tourists, thus supporting the activation of the regions. To this end, it is necessary to carry out detailed research in this area and to develop a plan of action to revive the local ports and their surroundings through the creation of regular passenger navigation along the coastal route E60.

\section{References}

1. Analiza stanu infrastruktury w portach rybackich i przystaniach pod katem dalszych potrzeb inwestycyjnych, Morski Instytut Rybacki, Gdynia 2012

2. H. Bierndgarski: Małe porty prą do przodu, Polska Dziennik Bałtycki, Baltexpo 2009, 1 września 2009

3. Cz. Christowa: Uwarunkowania funkcjonowania i rozwoju polskich portów morskich $\mathrm{W}$ : Funkcjonowanie $i$ rozwój polskich portów morskich w świetle zapisów "Zielonej Księgi" polityki morskiej Unii Europejskiej, VII Międzynarodowa Konferencja Naukowa "Porty Morskie 2007”, Pod red. K., Chwesiuka, Prace Monograficzne Akademii Morskiej w Szczecinie, Szczecin 2007

4. Formy aktywizacji rozwoju średnich i małych portów morskich polskiego wybrzeża. Modele zarządzania małymi portami - rekomendacje dla Polski. Kancelaria Senatu Biuro Analiz i Dokumentacji, Dział Analiz i Opracować Tematycznych, Warszawa 2010 
5. Formy aktywizacji rozwoju średnich i małych portów morskich polskiego wybrzeża, Kancelaria Senatu Biuro Analiz i Dokumentacji, Listopad 2010

6. A.S. Grzelakowski: Formy i kierunki aktywizacji rozwoju malych portów morskich w UE W: Dwa lata Polski morskiej w Unii Europejskiej, XXII Sejmik Morski, Świnoujście-Ystad, Zeszyty Morskie 2007

7. W. Kuszewski, Identyfikacja potencjalnych warunków determinujących rozwój portów lokalnych w aspekcie niebieskiego i zielonego wzrostu, Gdańsk 2017

8. W. Kuszewski, Przegląd prowadzonych badań nad niebieskim i zielonym rozwojem portów lokalnych, Gdańsk 2017

9. Lokalna Strategia Rozwoju na lata 2014-2020 Darłowskiej Lokalnej Grupy Rybackiej, Darłowska Lokalna Grupa Rybacka, Darłowo 2015

10. Lokalna Strategia Rozwoju na lata 2014-2020, Północnokaszubska Lokalna Grupa Rybacka 2012

11. Lokalna Strategia Rozwoju Obszarów Rybackich, Stowarzyszenie Lokalna Grupa Rybacka Pradolina Łeby, Gniewino 2013

12. Lokalna Strategia Rozwoju Słowińskiej Grupy Rybackiej 2014-2020, Słowińska Grupa Rybacka 2016

13. K. Luks: Polityka wobec portów lokalnych na przykładzie Portu Elbląg, 2009

14. J. Miszczuk: Problemy małych i średnich portów morskich z punktu widzenia administracji państwowej, Szczecin.

15. P. Nowaczyk: Małe porty morskie w strategiach rozwoju gmin nadmorskich. Przedsiębiorczość i Zarządzanie Wydawnictwo SAN, tom XVI, zeszyt 4, część I, s.57-72.

16. Plan rozwoju portu w Helu, Zarząd Portu Morskiego Koga 2009, http://www.porthel.home.pl/files/plan_rozwoju_portu_w_helu_2009.pdf

17. Program rozwoju polskich portów morskich do roku 2020 ( z perspektywą do 2030 roku), Ministerstwo Transportu, Budownictwa i Gospodarki Morskiej, Warszawa, Lipiec 2013

18. Rocznik Statystyczny Gospodarki Morskiej, Główny Urząd Statystyczny, Szczecin 2016

19. Strategia Rozwoju Gminy Miejskiej Łeba na lata 2014-2025, Listopad 2014.

20. Strategia Rozwoju Portu Morskiego Darłowo, Zarząd Portu Morskiego Darłowo, Darłowo 2007

21. Strategia rozwoju portu morskiego Kołobrzeg, Zarząd Portu Morskiego Kołobrzeg 2010, http://www.zpm.portkolobrzeg.pl/303, strategia-rozwoju-portu

22. Strategia Rozwoju Portu Morskiego Kołobrzeg, Zarząd Portu Morskiego Kołobrzeg Sp. z o.o., Kołobrzeg 2010

23. Strategia rozwoju portu morskiego w Ustce do roku 2021, Business Mobility International Sp. z o.o., Ustka 2007, www.christowaczeslawa.pl/.../2007-strategia-rozwoju-portu-morskiego-w-Ustce.pdf

24. Strategia Rozwoju Ziemi Puckiej na lata 2016-2025, Stowarzyszenie Północno Kaszubskie Lokalna Grupa Rybacka, kwiecień 2016.

25. Strona internetowa: http://ustka24.info/przebudowa-wejscia-portu-ustka/,

26. Strona internetowa: http://www.portalmorski.pl/morze-inne/bezpieczeństwo-i-srodowisko/39735-szykujesie-gigantyczna-przebudowa-wejscia-do-portu-w-ustce,

27. Strona internetowa: http://www.portalmorski.pl/porty-morskie/port-kołobrzeg,

28. Strona internetowa: www.gp.pl/strefa-biznesu/wiadomosci/z-regionu-a-wladze-ustki-maja-koncepcjenowego-portu-wizualizacja, 10172840 .

29. W. Szczurek, Działalność gospodarcza gmin w portach morskich, Fundacji Rozwoju Uniwersytetu Gdańskiego, Gdańsk (2002)

30. Ustawa z 20 grudnia 1996 r. o portach i przystaniach, Dz.U.2002, nr 110, poz. 967, z późn.zm.

31. Zarząd Portu Morskiego Darłowo (2007), Strategia rozwoju portu morskiego Darłowo - dokument, http://www.port.darlowo.pl/pl/?div=dokumenty [28 wrześnie 2014].

32. J. Zieziula, Identyfikacja czynników determinujących wielkość obrotów przeładunkowych w matych portach morskich na przykładzie Portu Darłowo, Uniwersytet Szczeciński

33. J. Zieziula, P. Nowaczyk: Identyfikacja czynników determinujących wielkość obrotów przeładunkowych w małych portach morskich na przykładzie Portu Darłowo, Szczecin. 